R. M. Tatsii, Dr. Sc. (Phys.-Math.), Prof., orcid.org/0000-0001-7764-2528,

O. Yu. Pazen, Cand. Sc. (Tech.), orcid.org/0000-0003-1655-3825,

S. Ya. Vovk, Cand. Sc. (Tech.), orcid.org/0000-0001-7007-7263
Lviv State University of Life Safety, Lviv, Ukraine, e-mail: opazen@gmail.com

\title{
MODELING OF THE HEAT TRANSFER PROCESS TAKING INTO ACCOUNT BURSTING EXPANSION OF FIRE-RETARDANT COATING
}

Purpose. To develop an algorithm for calculating the problem of determining the non-stationary temperature field through the thickness of a multilayered structure, taking into account changes in the thermophysical characteristics and geometric dimensions (fluctuations) of the applied fire protection coating.

Methodology. Application of the direct method for solving the differential equation of heat conduction using the method of reduction, the concept of quasi-derivatives, the method of separation of variables and the modified method of eigenfunctions of Fourier.

Findings. An algorithm for determining the non-stationary temperature field in a multilayered flat structure is proposed, taking into account changes in the thermophysical characteristics and geometric dimensions (bursting expansion process) of the fire protection coating. This is achieved by solving a sequence of two tasks (the temperature field before the swelling and after the swelling of the coating).

Originality. For the first time, using the direct method, in solving the problem of non-stationary heat conductivity, an algorithm for determining the temperature field in multilayer elements with variable thickness of a layer on the example of building structures with flame retardant systems based on intumescent coatings is proposed.

Practical value. Further, this approach can be implemented for approximation of solutions of heat conduction problems and it will allow catalyzing studies on fire retardant properties of intumescent coatings.

Keywords: direct method, thermal conductivity, non-stationary temperature field, flame retardant coating

Introduction. At all stages of capital construction or reconstruction of objects of different purposes it is necessary to count the ability of building structures to maintain the main properties in case of fire. So the heating of structures, which can lead to its premature destruction, should be avoided. As it is known, to protect the structures, their processing with fireproof compositions (coatings) is carried out. The usage of such coatings is a sufficiently effective way to save the main elements from heating. So, for example, intumescent flame retardant systems can prevent the heating of metal constructions to a critical temperature of $500{ }^{\circ} \mathrm{C}$ from 15 minutes (without fire protection) to 90 minutes.

Obviously, this kind of fire protection is very effective. However, during the research on the distribution of the non-stationary temperature field of such problems (structures with fire protective coatings) significant difficulties usually occur, because during the heating the coating swells, which leads to a change in the geometric size (thickness increase) and thermophysical characteristics (thermal conductivity coefficient, density and specific heat) of coating. As a rule, such a change is expressed by the coefficient of fluctuation, ranging from 10 to 15 times. Therefore, the development of methods for researching the problems of thermal conductivity, which take into consideration the change in the characteristics of the material, is an urgent task of the present.

Literature review. According to $[1,2]$ the assessment of the protective effect of the coating should be carried out by experimental methods. In the work [3] an experimental study on the flame retardant coating for steel under three different fire scenarios was done. In developing new types of coatings and defining their flame retardant properties, experimental studies are also often used, as it is done, for example, in [4].

In $[5,6]$, there are at least 5 nominal modes for which a fire may progress. Therefore, the inclusion of fire-retardant coating properties for each mode is a complicated task.

It should also be noted that real fire tests require powerful laboratories for testing, which will be able to provide the required level of requirements for experimental research and, as a result, carries significant financial costs.
Unsolved aspects of the problem. Analytical methods for investigating the non-stationary temperature field in the structures is an alternative to methods for assessing fire resistance of bearing walls based on standard fire tests. The analytical methods are conventionally divided into three types: a) direct or classical, which are based on the method of separation of variables [7]; b) operational, using various kinds of integral transformations $[8,9]$; c) approximate analytical and numerical methods [10]. However, these studies do not allow taking into account the swelling of the coating. Typically [6], the calculations are carried with the already swelled coating, which may not give a sufficiently accurate estimate of the time of fire protection.

The aim of this work is to use the direct method [11] to develop an algorithm for determining the temperature field of elements of building structures, taking into account changes in the geometric size and thermophysical characteristics (swelling process) of the fire protection coating.

Problem statement and its mathematical model. We consider a multilayered flat construction with thickness $l, m$ in a rectangular Cartesian coordinate system $0 x y z$. This area is bounded by the planes $x=x_{0}=0$ and $x=x_{n}=l$ and is divided by the planes $x=x_{0}, x=x_{1}, x=x_{2}, x=x_{n-1}$, on $\mathrm{n}$ layers of different thickness. Each layer has its own thermal conductivity $-\lambda, \mathrm{W} / \mathrm{m} \cdot{ }^{\circ} \mathrm{C}$; specific heat capacity $-c, \mathrm{~J} / \mathrm{kg} \cdot{ }^{\circ} \mathrm{C}$; and the density is $\rho, \mathrm{kg} / \mathrm{m}^{3}$. A fire occurs near one of the surfaces of the structure. After some time from the beginning of the fire, due to the thermal action of the flame, one of the layers changes its geometric dimensions and thermophysical characteristics (for example, there can be swelling of the fire protection coating). To determine the fire resistance limit of such a structure, it is necessary to solve a sequence of tasks for determination of the distribution of the non-stationary temperature field of a multilayered structure, taking into account the change in its geometrical and thermophysical characteristics.

The problem of the distribution of a non-stationary temperature field in the thickness of a multilayered flat construction is reduced to the solution on the interval $\left[x_{0}, x_{n}\right]$ of the differential equation $[8,11]$ 


$$
c(x) \rho(x) \frac{\partial t}{\partial \tau}=\frac{\partial}{\partial x}\left(\lambda(x) \frac{\partial t}{\partial x}\right),
$$

with boundary conditions of the third kind

$$
\left\{\begin{array}{l}
\alpha_{0} t\left(x_{0}, \tau\right)-t^{[1]}\left(x_{0}, \tau\right)=\alpha_{0} \psi_{0}(\tau) \\
\alpha_{n} t\left(x_{n}, \tau\right)+t^{[1]}\left(x_{n}, \tau\right)=\alpha_{n} \psi_{n}(\tau)
\end{array},\right.
$$

with initial condition

$$
t(x ; 0)=\varphi(x),
$$

where $t(x, \tau)$ is temperature, ${ }^{\circ} \mathrm{C} ; t^{[1]}(x, \tau)=\lambda t_{x}^{\prime}$ is quasi derivative (heat flux density with minus sign) [11]; $\alpha_{0} \& \alpha_{n}$ are heat transfer coefficients between the fire environment and the surface of the structure, $\mathrm{W} / \mathrm{m}^{2.0} \mathrm{C} ; \psi_{0}(\tau)=345 \lg ((8 \tau / 60)+1)+$ +20 is the fire temperature change law (standard temperature mode [5]); $\psi_{0}(\tau)=20$ is the ambient temperature on the side of the non-heated surface; $\tau$ is time, $\mathrm{s}$.

We introduce the following notation [11]:

$\theta_{i}-$ characteristic half-open interval function $\left[x_{i}, x_{i+1}\right)$

$$
\theta_{i}(x)=\left\{\begin{array}{l}
1, x \in\left[x_{i}, x_{i+1}\right), \\
0, x \notin\left[x_{i}, x_{i+1}\right),
\end{array} \quad i=\overline{0, n-1} .\right.
$$

Using notation (4) we are rewriting coefficients of equation (1) as

$$
\lambda(x)=\sum_{i=0}^{n-1} \lambda_{i} \theta_{i} ; \quad c(x) \rho(x)=\sum_{i=0}^{n-1} c_{i} \rho_{i} \theta_{i}
$$

In the future, we consider the coefficients $\lambda_{i}, c_{i}, \rho_{i}$ to be piecewise constants at each interval $\left[x_{i}, x_{i+1}\right)$.

The solution of equation (1-3) is sought as a sum of two functions (the method of reduction) [11]

$$
t(x, \tau)=u(x, \tau)+v(x, \tau) \equiv \sum_{i=0}^{n-1}\left[u_{i}(x, \tau)+v_{i}(x, \tau)\right] \theta_{i} .
$$

Any of the functions $u(x, \tau)$ or $v(x, \tau)$ can be chosen arbitrarily, then the other one will be determined unambiguously.

Choosing the function $\boldsymbol{u}(\boldsymbol{x}, \tau)$. Choosing a function $u(x, \tau)$ as a solution to a quasi-stationary problem [11]

$$
\left(\lambda u^{\prime}\right)^{\prime}=0,
$$

with boundary conditions of the third kind

$$
\left\{\begin{array}{l}
\alpha_{0} u\left(x_{0}, \tau\right)-u^{[1]}\left(x_{0}, \tau\right)=\alpha_{0} \psi_{0}(\tau) \\
\alpha_{n} u\left(x_{n}, \tau\right)+u^{[1]}\left(x_{n}, \tau\right)=\alpha_{n} \psi_{n}(\tau)
\end{array} .\right.
$$

It has been established in [11], [12] that the solution of the (quasi) stationary boundary value problem $(6,7)$ on the interval $\left[x_{i}, x_{i+1}\right)$ has the form

$$
u_{i}(x, \tau)=(1,0) \cdot \mathbf{U}(x, \tau)=B_{i}\left(x, x_{i}\right) \cdot B\left(x_{i}, x_{0}\right) \cdot \mathbf{P}_{0}(\tau),
$$

where it is marked

$$
\begin{gathered}
\mathbf{P}_{0}(\tau)=\left(P+Q \cdot B\left(x_{n}, x_{0}\right)\right)^{-1} \cdot \Gamma(\tau) ; \\
P=\left(\begin{array}{cc}
\alpha_{0} & -1 \\
0 & 0
\end{array}\right) ; \quad Q=\left(\begin{array}{cc}
0 & 0 \\
\alpha_{n} & 1
\end{array}\right) ; \\
\Gamma(\tau)=\left(\alpha_{0} \cdot \psi_{0}(\tau) ; \quad \alpha_{n} \cdot \psi_{n}(\tau)\right)^{T} ; \\
B_{i}\left(x, x_{i}\right)=\left(\begin{array}{cc}
1 & \frac{x-x_{i}}{\lambda_{i}} \\
0 & 1
\end{array}\right) ; \quad B\left(x_{i}, x_{0}\right)=\left(\begin{array}{cc}
1 & \sum_{k=0}^{i-1} \frac{x_{k+1}-x_{k}}{\lambda_{k}} \\
0 & 1
\end{array}\right) .
\end{gathered}
$$

Due to the corresponding mathematical calculations, the solution of the boundary value problem $(6,7)$ on the interval $\left[x_{i}, x_{i+1}\right]$ has the form

$$
\begin{aligned}
& u_{i}(x, \tau)=(1, \quad 0) \cdot U(x, \tau)= \\
& =\left(\begin{array}{cc}
1 & \frac{x-x_{i}}{\lambda_{i}} \\
0 & 1
\end{array}\right) \cdot\left(\begin{array}{cc}
1 & \sum_{k=0}^{i-1} \frac{x_{k+1}-x_{k}}{\lambda_{k}} \\
0 & 1
\end{array}\right) \frac{1}{\alpha_{0} \alpha_{n} \sum_{m=0}^{n-1} \frac{x_{m+1}-x_{m}}{\lambda_{m}}+\alpha_{0}+\alpha_{n}} \times \\
& \times\left(\left(\alpha_{n} \sum_{m=0}^{n-1} \frac{x_{m+1}-x_{m}}{\lambda_{m}}+1\right) \alpha_{0} \psi_{0}(\tau)+\alpha_{n} \sum_{m=0}^{n-1} \frac{x_{m+1}-x_{m}}{\lambda_{m}}\right) .
\end{aligned}
$$

Mixed problem for function $v(x, \tau)$. Using the notation (5) we rewrite the equation (1) in the following form [11]

$$
c \rho \frac{\partial u}{\partial \tau}+c \rho \frac{\partial v}{\partial \tau}=\frac{\partial}{\partial x}\left(\lambda \frac{\partial u}{\partial x}\right)+\frac{\partial}{\partial x}\left(\lambda \frac{\partial v}{\partial x}\right)
$$

Taking into account that $u(x, \tau)$ is a solution of the problem $(6,7)$, the equation (9) will take the form

$$
c \rho \frac{\partial u}{\partial \tau}+c \rho \frac{\partial v}{\partial \tau}=\frac{\partial}{\partial x}\left(\lambda \frac{\partial v}{\partial x}\right)
$$

It should be noted that function $c \rho \frac{\partial u}{\partial \tau}$ is to be known because function $u(x, \tau)$ is already known.

Whereas function $u(x, \tau)$ fulfills the boundary conditions (2), so conditions for function $v(x, \tau)$ follow from (5)

$$
\left\{\begin{array}{l}
\alpha_{0} v\left(x_{0}, \tau\right)-v^{[1]}\left(x_{0}, \tau\right)=0 \\
\alpha_{n} v\left(x_{n}, \tau\right)+v^{[1]}\left(x_{n}, \tau\right)=0
\end{array},\right.
$$

and the initial condition looks like

$$
v(x, 0)=f(x) \equiv \varphi(x)-u(x, 0)=\sum_{i=0}^{n-1}\left[\varphi_{i}(x)-u_{i}(x, 0)\right] \theta_{i} .
$$

The structure of the solution of a mixed problem (10-12) has been studied and described in detail in [11]. This solution can be constructed as follows:

1. Characteristic equation of the problem on its own states has a view

$$
\begin{gathered}
\Phi(\omega)=\operatorname{def}\left(P+Q \cdot B\left(x_{n}, x_{0}, \omega\right)\right)=0 ; \\
\widetilde{B}\left(x_{i}, x_{0}, \omega\right) \stackrel{d f}{=} \\
=\prod_{j=0}^{i}\left(\begin{array}{cc}
\cos \alpha_{i-j}\left(x_{i-j+1}-x_{i-j}\right) & \frac{\sin \alpha_{i-j}\left(x_{i-j+1}-x_{i-j}\right)}{\lambda_{i-j} \alpha_{i-j}} \\
-\lambda_{i-j} \alpha_{i-j} \sin \alpha_{i-j}\left(x_{i-j+1}-x_{i-j}\right) & \cos \alpha_{i-j}\left(x_{i-j+1}-x_{i-j}\right)
\end{array}\right) ; \\
\alpha_{i-j}=\sqrt{\frac{c_{i-j} \rho_{i-j} \omega}{\lambda_{i-j}}} .
\end{gathered}
$$

We can find the own states $\omega_{k}$. from equation (13).

2. Eigen functions $X_{k}$ which conform to the corresponding eigenvalues $\omega_{\mathrm{k}}$, have the following structure

$$
\begin{aligned}
& X_{k i}\left(x, \omega_{k}\right)=(1, \quad 0) \cdot\left(\begin{array}{cc}
\cos \alpha_{i}\left(x-x_{i}\right) & \frac{\sin \alpha_{i}\left(x-x_{i}\right)}{\lambda_{i} \alpha_{i}} \\
-\lambda_{i} \alpha_{i} \sin \alpha_{i}\left(x-x_{i}\right) & \cos \alpha_{i}\left(x-x_{i}\right)
\end{array}\right) \times \\
& \times \tilde{B}\left(x_{i}, x_{0}, \omega_{k}\right) \cdot\left(\begin{array}{c}
\frac{1}{\alpha_{0}} \\
1
\end{array}\right) \text {, }
\end{aligned}
$$

where it is noted $\alpha_{i}=\sqrt{\frac{c_{i} \rho_{i} \omega_{k}}{\lambda_{i}}}$.

3. The square of norm $\left\|X_{k}\right\|^{2}$ of eigen functions $X_{k}\left(x, \omega_{k}\right)$ has a view 


$$
\left\|X_{k}\right\|^{2}=\sum_{i=0}^{n-1} c_{i} \rho_{i} \cdot \int_{x_{i}}^{x_{i+1}} X_{k i}^{2}\left(x, \omega_{k}\right) d x .
$$

4. The Fourier coefficients of development of the initial function $f(x)$

$$
f_{k}=\frac{1}{\left\|X_{k}\right\|^{2}} \sum_{i=0}^{n-1} c_{i} \rho_{i} \int_{x_{i}}^{x_{i+1}} f_{i}(x) X_{k i}\left(x, \omega_{k}\right) d x .
$$

5. The Fourier coefficients of development of the function $\frac{\partial u}{\partial \tau}$

$$
\beta_{k}(s)=\frac{1}{\left\|X_{k}\right\|^{2}} \sum_{i=0}^{n-1} c_{i} \rho_{i} \int_{x_{i}}^{x_{i+1}} \frac{\partial u_{i}(x, s)}{\partial s} X_{k i}\left(x, \omega_{k}\right) d x .
$$

On each of the spaces $\left[x_{i}, x_{i+1}\right]$, this solution is depicted in expanded form

$v_{i}(x, \tau)=\sum_{k=1}^{\infty}\left[f_{k} \cdot e^{-\omega_{k} \tau}-\int_{0}^{\tau} e^{-\omega_{k}(\tau-s)} \beta_{k}(s) d s\right] X_{k i}\left(x, \omega_{k}\right)$.

Using the Figure (5) and taking into account formulas (8) and (14), we finally obtain the solution of the problem (1-3) in the form

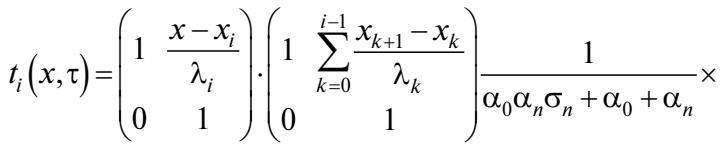

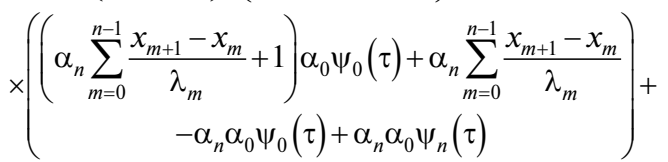

$$
\begin{aligned}
& +\sum_{k=1}^{\infty}\left[f_{k} e^{-\omega_{k} \tau}-\int_{0}^{\tau} e^{-\omega_{k} \tau} \beta_{k}(s) d s\right] X_{k i}\left(x, \omega_{k}\right) .
\end{aligned}
$$

Application of the solution. To study the influence of thermophysical and geometrical (thickness of the dry layer) characteristics of flame retardant coatings on fire resistance of structures we consider a reinforced concrete slab protected by a flame retardant coating.

To investigate the distribution of the temperature field in the thickness of the reinforced concrete slab (at a depth of $20 \mathrm{~mm}$ - the expected location of the reinforcement in the concrete slabs), protected by the fireproof coating Polylack-A produced by the Hungarian firm "Dunamenti Túzvédelem Zrt", we simulate it in the form of a two layer structure with a thickness of the fire protective coating of $2 \mathrm{~mm}$. The temperature on one side of the slab changes according to the standard temperature mode of the fire. We consider two stages of the heating process of the slab with fire protection: before swelling and after swelling of the coating.

In the paper [6] it is indicated that during intense heating the fire protection coating swells at a temperature of about $250{ }^{\circ} \mathrm{C}$ and, as a result, its thermophysical characteristics and geometrical sizes change. In particular, the thickness of the coating during flutter increases by $10-15$ times, and the thermal conductivity and density decrease respectively. This, in turn, reduces the heating intensity of the structure.

Stage before swelling. To investigate the distribution of a nonstationary temperature field in the thickness of a two-layer construction we used the direct method described above. This study was conducted using the computer algebra system Maple 13. The initial data of a two-layer structure were introduced as follows: the thickness of the layers; thermophysical characteristics of materials; the law of temperature changes on external surface layers (on the exposed surface the temperature varied according to the law of the standard temperature mode of the fire, on the other surface the temperature was constant); and the initial distribution of the temperature field until the start of the fire. Calculations show that the time of swelling of the Polylack-A flame retardant coating (reaching the temperature of the swelling) is 18 minutes (Fig. 1). It should be noted that in order to achieve this result, 30 roots of the characteristic equation (13) and corresponding summation of the terms of series (14) were calculated.

Stage after swelling. During the second stage, a new task is set. Due to this task the thermophysical characteristics and the geometric dimensions of the coating vary. The initial distribution of the temperature field over the thickness of the structure also changes (the temperature field, which was at the time of the swelling of the coating - in the $18^{\text {th }}$ minute of the first stage - was introduced). The heating of the exposed surface does not begin anew, but conditionally continues (from the $18^{\text {th }}$ minute). By introducing new initial data, and using the computer algebra system Maple 13 [12-15], we obtain the distribution of the non-stationary temperature field in the thickness of a two-layer structure in the form of a graph (Fig. 2).

Fig. 3. shows the process of heating of flame retardant coating during all period of fire.

To estimate the heating of the reinforcement at a depth of $20 \mathrm{~mm}$, a plot of the distribution of the non-stationary temperature field in time is constructed, taking into account the process of swelling of the fire protection coating.

The analysis of Fig. 4 makes it possible to establish that the reinforcement in the reinforced concrete floor slab, protected by a fireproof coating, is heated to a critical temperature of $500{ }^{\circ} \mathrm{C}$ for 181 minutes.

Now let us investigate the distribution of the temperature field in the thickness of the reinforced concrete slab (at a depth of $20 \mathrm{~mm}$ ), without taking into account the stage before the swelling of the flame retardant. Calculations are conducted for a double-layer construction with the already swelled flame retardant coating. The results are shown in Fig. 5.

The comparative analysis of Figs. 4 and 5 shows that after taking into account the swelling of the coating the temperature



Fig. 1. Heating of flame retardant coating (before swelling)

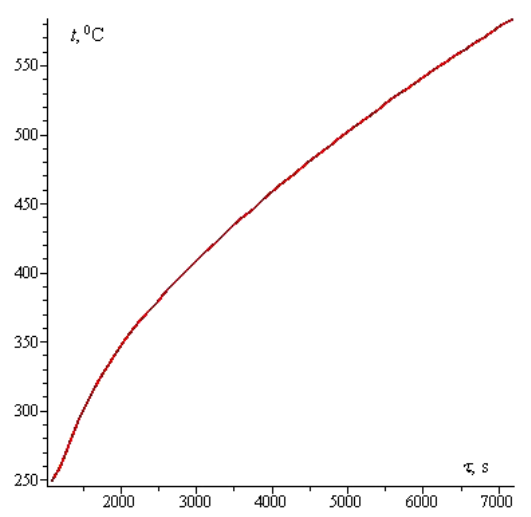

Fig. 2. Heating of flame retardant coating (after swelling) 
of the structure reaches $500{ }^{\circ} \mathrm{C}$ in 181 minutes, and without taking into account the swelling of the coating the temperature of the structure reaches $500{ }^{\circ} \mathrm{C}$ in 195 minutes, which shows differences between various approaches to estimating the fire protection time of the coating.

Algorithm of the calculation. Due to the research conducted, an algorithm for determining the distribution of a non-stationary temperature field of a multilayer structure with the possibility of changing the geometric sizes and thermophysical characteristics of the flame retardant coating layer was developed. The algorithm is based on the direct method for calculating the non-stationary temperature field throughthe-thickness of a multilayered flat structure.

1. The first stage of the proposed algorithm is the input of the initial data.

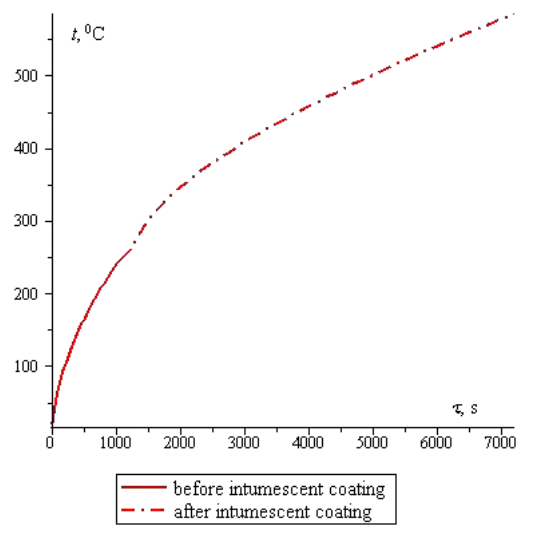

Fig. 3. Heating of flame retardant coating during the whole period of fire



Fig. 4. Heating of a reinforced concrete floor slab (taking into account swelling of the coating)

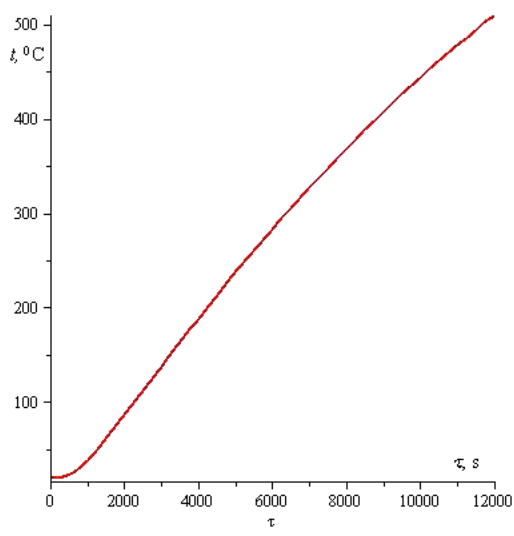

Fig. 5. Heating of the reinforced concrete slab (without taking into account the swelling of the coating)
2. The next step is to calculate the non-stationary temperature field through the thickness of the multilayered flat structure, which is given in the formula (15).

3 . The calculation is made until the heating of the structure to the critical temperature, or swelling of the fire protection coating of the structure.

4. If the design does not warm up to a certain critical temperature, and the effect of the fire has led to the swelling of the fire protection coating of the structure, the calculations are stopped, and the time $\tau_{0}$ is fixed. Next, a new task is proposed for calculating the distribution of the non-stationary temperature field through-the-thickness of the structure, taking into account changes in the geometrical sizes and thermophysical characteristics of the swelled fire protection coating. New initial data is entered. The time $\tau_{0}$ is added to the law of temperature change of the fire $\psi_{0}(\tau)$ and the temperature of the environment $\psi_{n}(\tau)$. The initial distribution of the temperature field is given as a function of the distribution of the temperature field that existed at the time $\tau_{0}$. Again, the calculation of the distribution of the nonstationary temperature field through-the-thickness of the structure is made prior to heating it to a certain critical temperature.

5. If the heating of the structure is at a critical temperature before the swelling of the coating, the calculation is stopped.

6 . The results of the calculation are deduced in the form of explicit formulas for the distribution of the non-stationary temperature field for each of the layers of the structure. With the help of these formulas, the result can be deduced in the form of tabular data, graphic dependencies (bulk graphs, animations, and so on) changes in temperature through-thethickness of the construction, depending on the time.

Conclusions. The scheme of solving the boundary value problem of heat conductivity on the basis of the direct method is described, which allows us to create an algorithm for determining the distribution of a non-stationary temperature field, taking into account changes in the thermophysical and geometric characteristics of the structure. Boundary conditions of the third kind most successfully describe the process of transfer of heat between the design and the environment of the fire. The function of changing the temperature of the environment in time can be arbitrary, which allows describing various fire regimes, including parametric. The structure of the obtained explicit formulas $(8,14$ and 15$)$ allowed creating an algorithm for determining the temperature fields in the form of an automated program, where it is enough to enter only the initial data. Note that the basis of such algorithms is the procedures for calculating the roots of the characteristic equation, multiplying the finite number of matrices, calculating certain integrals, and summing the required number of members of the series (14) to obtain the given accuracy.

An arbitrary record of the initial condition (3) allows terminating the calculation at any time and change the size or thermophysical characteristics of the coating.

This method is verified in comparison with experimental studies. The results obtained using mathematical models, are qualitatively and quantitatively convergent with the results obtained experimentally. The difference between the theoretical and experimental data does not exceed $10 \%$, which is described in more detail in the work.

Distribution of this method on the construction of other geometric forms (cylindrical or spherical) does not cause significant difficulties.

As a product, in the future, this algorithm will significantly accelerate the study of flame retardant properties of intumescent coatings.

According to the authors, in the future, such an approach can be used to approximate the solutions of nonlinear heat conduction problems, but at present, this issue remains unresolved.

\section{References.}

1. Budstandart (n.d.). ДСТУ-Н-П Б В.1.1-29: 2010 Protection from fire. Fireproofing of building constructions. General 
requirements and control methods. Retrieved from http://online.budstandart.com/ru/catalog/doc-page?id_doc $=26657$. 2. International Organization for Standardization (ISO) (1999). ISO834-1, Fire Resistance Tests - Elements of Building Construction - Part 1: General Requirements for Fire Resistance Testing. Geneva, Switzerland. Retrieved from https://www. iso.org/standard/2576.html.

3. Lucherini, A., Giuliani, L., \& Jomaas, G. (2018). Experimental study of the performance of intumescent coatings exposed to standard and non-standard fire conditions. Fire Safety Journal, 95, 42-50.

4. Beheshti, A., \& Heris, S. Z. (2015). Experimental investigation and characterization of an efficient nanopowder-based flame retardant coating for atmospheric-metallic substrates. Powder technology, 269, 22-29.

5. Franssen, J.-M., \& Real, V. P. (2002). Eurocode 1: Actions on structures - Part 1-2: General actions - Actions on structures exposed to fire. https://doi.org/10.1002/9783433601570.ch1.

6. Subota, A. V., Semerak, M. M., \& Stokalyuk, O. V. (2014). Definition and study of the temperature field in the elements of metal constructions under the conditions of the temperature mode of hydrogen combustion. Pozhezhna bezpeka: $z b$. nauk. pr. LDUBZHD, (24), 120-123.

7. Singh, Suneet, \& Prashant, K. Jain (2016). Analytical solution for three-dimensional, unsteady heat conduction in a multilayer sphere. Journal of Heat Transfer, 138.10: 101301. https://doi.org/10.1115/1.4033536.

8. Xiao-Jun, Y. (2017). New integral transforms for solving a steady heat transfer problem. Jornal of Thermal Science, Supplement, 21, S79-S87.

9. Yue Zhang, \& Xiaofeng Li (2018). Heat transfer formalism using GFM and FEM in underground tunnels. Building and Environment, 143(1), 717-726.

10. Özişik, M.N., Orlande, H.R. B., Colaço, M.J., \& Cotta, R. M. (2017). Finite Difference Methods in Heat Transfer ( $2^{\text {nd }}$ ed.). New York: CRC Press.

11. Pazen, O. Y., \& Tatsii, R. M. (2016). General boundaryvalue problems for the heat conduction equation with piecewise-continuous coefficients. Journal of Engineering Physics and Thermophysics, 89(2), 357-368. https://doi.org/10.1007/ s10891-016-1386-8.

12. Pazen, O.Y. (2017). Mathematical modelling and computer simulation of direct method for studying boundary value problem of thermal conductivity. Problems of Infocommunications. Science and Technology, 73-76. https://doi.org/10.33108/ visnyk tntu2019.01.113.

13. Ildikó Perjési-Hámori (2015). Two Dimensional Mathematical Model of Heat-transmission Using MAPLE. IFACPapersOnLine, 48(1), 689-690.

14. Hashim A. Saber (2016). Using maple, maple 3D graphics, and tablet PC to teach calculus II and III. In $13^{\text {th }}$ Learning and Technology Conference (L\&T), (pp. 45-50). Retrieved from https://ieeexplore.ieee.org/document/7562864.

15. Pazen, O.Y. (2018). Verification results of the presentation of the protection of the unsteading temperature field at the concrete construction for the mind of the standard temperature refrigeration fire. Bulletin of Lviv State University of Life Safety, 18, 96-101. https://doi.org/10.32447/20784643.18.2018.10.

\section{Моделювання процесу теплопереносу з урахуванням спучення вогнезахисного покриття}

\section{Р. М. Таиій, О. Ю. Пазен, С. Я. Вовк}

Львівський державний університет безпеки життєдіяльності, м. Львів, Україна, e-mail: opazen@gmail.com

Мета. Розробити алгоритм розрахунку задачі про визначення нестаціонарного температурного поля за товщиною багатошарової конструкції з урахуванням зміни теплофізичних характеристик і геометричних розмірів (спучення) нанесеного вогнезахисного покриття.

Методика. Застосування прямого методу розв'язування диференціального рівняння теплопровідності із застосуванням методу редукції, концепції квазіпохідних, методу відокремлення змінних і модифікованого методу власних функцій Фур'є.

Результати. Запропоновано алгоритм визначення нестаціонарного температурного поля в багатошаровій пласкій конструкції з урахування зміни теплофізичних характеристик і геометричних розмірів (процес спучення) вогнезахисного покриття. Це досягається шляхом розв'язування послідовності двох задач (температурне поле до спучення та після спучення покриття).

Наукова новизна. Уперше із застосування прямого методу щодо розв'язку задачі нестаціонарної теплопровідності, запропоновано алгоритм щодо визначення температурного поля в багатошарових елементах зі змінною товщиною шару на прикладі будівельних конструкцій із вогнезахисними системами на основі покриттів, що спучуються.

Практична значимість. У подальшому такий підхід може бути використаний для апроксимації розв'язків нелінійних задач теплопровідності та дозволить значно пришвидшити дослідження вогнезахисних властивостей покриттів що спучуються.

Ключові слова: прямий метод, теплопровідність, нестаціонарне температурне поле, вогнезахисне покриття

\section{Моделирование процесса теплопереноса с учетом вспучивания огнезащитного покрытия}

\section{Р. М. Таций, О. Ю. Пазен, С. Я. Вовк}

Львовский государственный университет безопасности жизнедеятельности, г. Львов, Украина, e-mail: opazen@ gmail.com

Цель. Разработать алгоритм расчета задачи об определении нестационарного температурного поля по толщине многослойной конструкции с учетом изменения теплофизических характеристик и геометрических размеров (вспучивание) нанесенного огнезащитного покрытия.

Методика. Применение прямого метода решения дифференциального уравнения теплопроводности с применением метода редукции, концепции квазипроизводных, метода разделения переменных и модифицированного метода собственных функций Фурье.

Результаты. Предложен алгоритм определения нестационарного температурного поля в многослойной плоской конструкции с учетом изменения теплофизических характеристик и геометрических размеров (процесс вспучивания) огнезащитного покрытия. Это достигается путем решения последовательности двух задач (температурное поле до вспучивания и после вспучивания покрытия).

Научная новизна. Впервые с применением прямого метода по решению задачи нестационарной теплопроводности, предложен алгоритм об определении температурного поля в многослойных элементах с переменной толщиной слоя на примере строительных конструкций с огнезащитными системами на основе вспучивающихся покрытий.

Практическая значимость. В дальнейшем такой подход может быть использован для аппроксимации решений нелинейных задач теплопроводности и позволит значительно ускорить исследования огнезащитных свойств вспучивающихся покрытий.

Ключевые слова: прямой метод, теплопроводность, нестационарное температурное поле, огнезащитное покрытие

Recommended for publication by M. M. Semerak, Doctor of Technical Sciences. The manuscript was submitted 20.03.19. 